\title{
The Impact of Stakeholders on Health Services Development: An Empirical Investigation on the Surgical Department at King Fahd General Hospital, Saudi Arabia
}

\author{
Ala'Eddin Mohammad Khalaf Ahmad ${ }^{1}$ \\ ${ }^{1}$ Services Marketing Faculty of Economics and Administration, King Abdul-Aziz University, Saudi Arabia \\ Correspondence: Ala'Eddin Mohammad Khalaf Ahmad, Services Marketing Faculty of Economics and \\ Administration, King Abdul-Aziz University, Saudi Arabia. Tel: 966-56-852-7444. E-mail: \\ amahmed1@kau.edu.sa or aladdin.a.h@hotmail.com
}

Received: December 6, 2016

Accepted: January 2, 2017 Online Published: January 16, 2017

doi:10.5539/ijms.v9n1p129

URL: http://dx.doi.org/10.5539/ijms.v9n1p129

\begin{abstract}
The current research investigates the stakeholders influencing health services development at King Fahd General Hospital KFGH in Jeddah city, Saudi Arabia. This study proposes and tests a six factors model that influences health services development. These factors include government regulations, competitors, suppliers, patients, public, and health service providers as independent variables; the dependent variable is health services development. In order to explore this issue, a quantitative method was used to collect primary data through a questionnaire, which was administered in KFGH in Jeddah city in Kingdom of Saudi Arabia. The researches targeted 141 surgeons in this research as a sample because of the small population. A purposive sample was used to choose the participants in this research. The research retrieves 130 valid questionnaires; representing $92 \%$.The results confirm significant differences in the influence of these factors on health service development. The research concludes that there is a significant influence of governmental regulations, competitors, suppliers, patients, public, and health service providers on health services development. The research recommends enhancing the awareness of stakeholder factors by studying the effects of governmental regulations, competitors, suppliers, patients, public, and health service providers. The last is adopting and updating medical and non-medical technology to maintain health service development.
\end{abstract}

Keywords: stakeholders, health service development, private hospitals, Saudi Arabia

\section{Introduction and Background}

Recent times have been characterized by rapid change, knowledge explosion, technological advancement, and intense competition (Cummings, 1990). Some theorists are calling for major changes in the way service organizations, as well as manufacturing organizations, function. The environmental turbulence that has been created by healthcare reform and enhanced competitive pressures of the marketplace has meant that hospital executives have tried forcefully to develop and implement strategies that are most closely tied to their hospitals' distinctive competences and the executives' perception of their external environment. Hospital executives face myriad challenges, ranging from higher patient expectations to lower costs and possibly a restructuring of the total healthcare system due to the changing economics of healthcare (Ahmad, 2012). Marketing management's job is to build relationships with customers by creating customer value and satisfaction at the first step and then trying to build customer loyalty. However, marketing managers cannot do this alone. There are many major actors among the stakeholders (e.g., government regulations and legislations, suppliers, and competitors) playing critical roles to build such relations on the one hand; however, on the other hand developing the health service strategy which the customers expect and waiting for the private sector hospitals changing at an accelerating pace, leads to a high level of uncertainty. This growing uncertainty is the result of greater customer expectations, the dilution of borders between stakeholders, and the move towards global competition (Kotler, 2008). As there is an increasing level of dynamics in business, new strategies to separate the organization from its competitors become the key success factor. Consequently, industrialist and researchers have focused on the study of parameters affecting the development of strategy (Ahmad, 2012). The stakeholders include those elements or groups that directly affect, and are affected by, an organization's major operations. Studying stakeholder is an imperative issue as far as the expanded weight set upon hospitals and the competition that exists between hospitals. Scholars 
classify stakeholders as primary or secondary, based on the type of relationships they entertain with the organization. The primary refers to employees, suppliers, customers, and public agencies engaged in formal relationships with the organization. The secondary stakeholder groups incorporate performing artists, for example, the media and special interest groups, not engaged in formal transactions with the organization.

A stakeholder is often referred to as the industry in which the organization operates and includes those elements or groups that directly affect and are affected by an organization's major operation. According to Hitt et al. (1999), the industrial organization model challenges organizations to locate the most attractive industry sector in which to compete, as the basic premise of this environmental model of competitive advantage is based on the contention that competitiveness in general can be increased only when (a) organizations are able to find the industry, which proves to be attractive in terms of having the highest profit potential; and when (b) organizations are able to compete successfully in such an industry sector, through learning how to develop and use their internal resources and skills to implement the generic competitive strategy required by the structural characteristics in that industry. Stakeholders are rapidly changing, which can cause much uncertainty. This growing uncertainty is the result of greater customer expectations, the dilution of borders between stakeholders and the move towards global competition. As the level of dynamics in business situations builds, the advancement of strategies that will differentiate the organization from the competition is considered the most important success factor. Consequently, the study of parameters influencing the strategic advancement procedure has ended up a leading focus for industrialists and researchers. Emerson \& Grimm (1999) discriminated between strategic and environmental variables for hospitals, where the former are those over which the organization has influence, including how much flexibility there is, and the nature and quantity of the organization's advertising and promotion. The latter variables, however, are those outside the organizations' control, such as the amount of competition or rivalry in the industry. Wheelen \& Hunger (2002) agree that top management need to extensively scan the changes in environmental factors to develop effective corporate policies for both short- and long-term missions. However, the implementation of these policies is dependent on individual perceptions and interpretations of environmental uncertainty.

When health services are being marketed, competition for resources and contracts, whether actual or potential, forces health organizations to become more strategic in their market planning. As a result of this, Scrivens (1991) believes that public services may now be exhibiting greater competitor focus in response to such internal market pressures. According to Green et al. (1995), healthcare providers must control rising costs, improve the productivity and flexibility of human resources, adopt appropriate technologies and learn to establish and maintain quality and competitive abilities in the marketplace. These researchers also suggest that healthcare firms are faced with an extremely uncertain environment that makes planning onerous. Several activities which directly affect the hospital industry include the labor market, technology market, capital market, supplier, customer market and payer market. The customer market differs from that of traditional firms because of its product relationship. Physicians are considered primary customers because they often select the product (or supplier of the product) for a secondary customer who is known as the patient. In the healthcare context, hospitals could engage in cooperative and collaborative arrangements with several groups of customers, including patients, payers and health insurance companies. They could also partner with their suppliers, other hospitals and / or specialized healthcare service providers to enhance their offerings to customers. These arrangements could broadly be classified into three types of relationship exchange: (1) programmes that are aimed at customer retention; (2) programmes that involve special arrangements for supply and delivery with other healthcare marketers and crucial suppliers; and (3) relational partnering programmes to leverage the resources of others. The concept of uncertainty is among the terms which frequently describe this crucial feature of the healthcare environment. Begun \& Kaissi (2004) defined uncertainty as an occurrence where decision-makers do not possess enough background facts or figures to allow proper and accurate analysis of the diverse environment. They suggested that healthcare organizations deal with a significant number of external elements. For example, suppliers, competitors, customers, financial capital markets, government regulatory agencies, institutions, professional associations, trade unions, healthcare professionals and insurer-payers are among the major external elements. Therefore, healthcare providers require a management approach that takes maximum advantage of those force-driving changes in both the industry and organizations within the industry. Organizations including hospitals, physicians' clinics, home health agencies and extended care facilities must identify new methods of gaining and keeping market share to successfully compete in such an industry, which is market-driven and customer-focused. The research problem revolves around investigating the impact of stakeholders on health services development in KFGH in Jeddah. This research will try to answer the following questions: What are the main stakeholder factors influencing health services improvement in surgical department at KFGH? Is the government factor influencing the health services improvement in surgical department at KFGH? 
Is the competitors factor influencing the health services improvement in surgical department at KFGH? Is the suppliers factor influencing the health services improvement in surgical department at KFGH? Is the patients factor influencing the health services improvement in surgical department at KFGH? Is the public factor influencing the health services improvement in surgical department at KFGH? Is the health service providers factor influencing the health services improvement in surgical department at KFGH? The current research paper is trying to investigate the impact of stakeholders on health services development at King Fahd General Hospital, Saudi Arabia.

\section{The Rationale of Research}

This research will make a positive contribution in the direct antecedents of stakeholders influencing the health services development in surgical department at KFGH. The specific references only partially covered the antecedents of stakeholders with health services development. The research contribution will be beneficial both academically and professionally. Academically, this work aims to focus academic attention upon a neglected domain in the context of this research. And, professionally, managers will also look at the practical implications of such effort and the possibility of implementing the implication of this research in their actual relationships with their stakeholders. Therefore, the present study attempts to fill a gap in the subject of stakeholders and its consequences in KFGH.

\section{Research Objectives}

Based on the above section highlighting the stakeholders in health services development in KFGH, the objectives of this research are:

1) To identify the factors which constitute the stakeholders in surgical department in KFGH in Jeddah city.

2) To investigate the impact of stakeholders factors on surgical department (government regulation, patients, suppliers, public, competitors, and health service providers) components of health services development at KFGH in Jeddah city.

\section{Research Model}

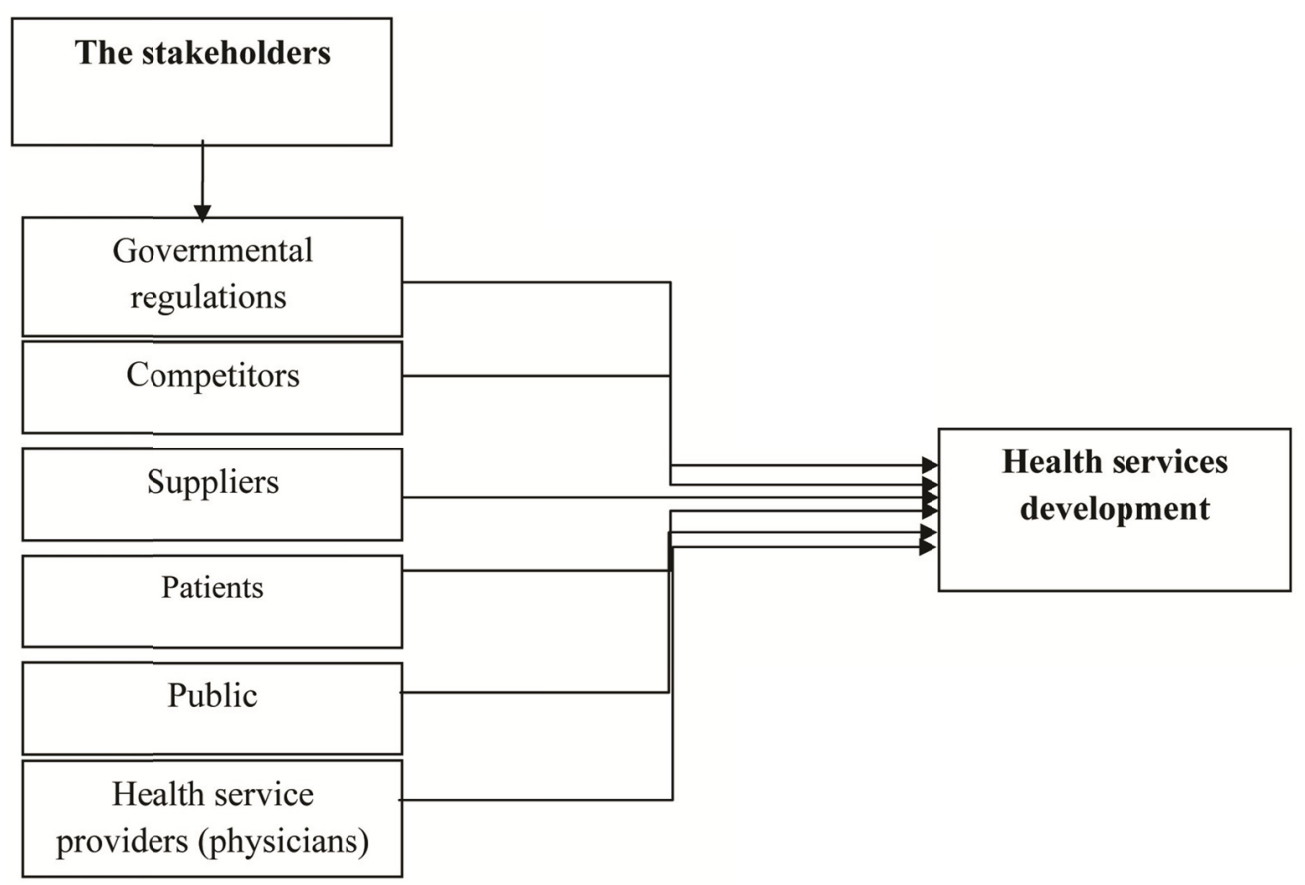

\section{Research Hypotheses}

The general hypothesis in this research is:

There is a significant relationship between stakeholders and health services development at KFGH in Jeddah city.

The research sub-hypotheses are as follows: 
1) There is a significant relationship between governmental regulations and health services development.

2) There is a significant relationship between competitors and health services development.

3) There is a significant relationship between suppliers and health services development.

4) There is a significant relationship between patients and health services development.

5) There is a significant relationship between public and health services development.

6) There is a significant relationship between health service providers and health services development.

\section{Research Methodology}

This research is a descriptive analytical study using a cross-sectional survey in which all ten surgical departments accounted for 141 surgeons of KFGH. It is a single cross-sectional design, with information from the respondents collected only once. The population in this research is defined as all the surgical doctors who are working at surgical department in all levels (consultants, specialists, and residents). The research population consisted of 141 surgical doctors. The research sample of the current study was all the research population because of the small number of the research population. The research questionnaire was distributed for all the surgeons in all surgical departments (general surgery, orthopedic surgery, ENT surgery, urology surgery, vascular surgery, plastic surgery, cardiac surgery, neurosurgery, pediatric surgery, and ophthalmology department). The research retrieved 130 valid questionnaires, which represented $92 \%$.

In this research, a quantitative approach was used for the purpose of gaining a comprehensive picture of the issues in question. The current research used the questionnaire techniques to collect the primary data. The research questionnaire was designed based on previous empirical literature. The components of factors influencing health service development (governmental regulations, competitors, suppliers, patient, public, and health service providers) were measured on a five-point Likert-scale ranging from 5 (strongly agree) to 1 (strongly disagree). The questionnaire design was pre-tested and redesigned through academic staff in health services department and personal interviews with senior staff from specialists from different surgery departments at KFGH undertaking the pilot study work. The features related to each component of health service development are dependent variables.

\section{Reliability}

Reliability describes how much an experiment, test, or other measure able procedure is repeatable in its results when the trial is conducted again (APA, 1985). Without the agreement of independent observers able to replicate research processes, or the capability of using research techniques and practices which yield consistent measurements, researchers would be unable to satisfactorily draw conclusions, formulate theories, or make claims about the generalizability of their research.

In this research, the researcher has used the Split Half method to assess the reliability of the questionnaire sections. Table 1 presents the results of the Split Half method for questionnaire reliability:

Table 1. Split half method of the questionnaire

\begin{tabular}{lll}
\hline Section & Correlation Coefficient & Modified Correlation Coefficient \\
\hline Governmental regulations & 0.753 & 0.762 \\
Competitors & 0.619 & 0.623 \\
Suppliers & 0.748 & 0.811 \\
Patient & 0.820 & 0.824 \\
Public & 0.753 & 0.762 \\
Health services providers & 0.619 & 0.623 \\
Health service development & 0.748 & 0.811 \\
\hline
\end{tabular}

From the above table, the Split Half method was calculated for each section of the questionnaire and these coefficients are acceptable as the questionnaire is used for the first time. The questionnaire is then considered a reliable tool.

\section{Data Analysis and Discussion}

\subsection{General Demographic Analysis}

Describing the relationship between a sample and its population is very important. This section is, therefore, largely concerned with presenting a descriptive analysis of the sample to evaluate and provide an overview of the 
respondents' characteristics according to the following criteria.

Table 2. Frequency and percentage for demographic information

\begin{tabular}{|c|c|c|c|}
\hline & & Frequency & Percentage \\
\hline \multirow{6}{*}{ Age } & Under 30 years & 22 & 16.9 \\
\hline & $30-40$ years & 35 & 26.9 \\
\hline & $41-50$ years & 32 & 24.6 \\
\hline & $51-60$ years & 37 & 28.4 \\
\hline & More than 60 years & 4 & 3 \\
\hline & Total & 130 & 100.0 \\
\hline \multirow{5}{*}{ Education Level } & Bachelor & 23 & 17.6 \\
\hline & Master & 53 & 40.7 \\
\hline & $\mathrm{PhD}$ & 40 & 30.7 \\
\hline & Other & 14 & 10.7 \\
\hline & Total & 130 & 100.0 \\
\hline \multirow{4}{*}{ Clinical Degree Background } & Consultant & 44 & 33.8 \\
\hline & Specialist & 60 & 46.1 \\
\hline & Resident & 26 & 20 \\
\hline & Total & 130 & 100.0 \\
\hline \multirow{6}{*}{$\begin{array}{l}\text { Number of years you } \\
\text { have been working in the } \\
\text { health services sector }\end{array}$} & Less than 5 & 24 & 18.4 \\
\hline & $5-9$ & 24 & 18.4 \\
\hline & $10-15$ & 24 & 18.4 \\
\hline & $16-20$ & 36 & 27.6 \\
\hline & More than 20 & 22 & 16.9 \\
\hline & Total & 130 & 100.0 \\
\hline
\end{tabular}

Table 2 shows that:

1) The highest percentage for "age" reached (28.4\%) for age category 51-60 years, but the lowest percentage reached $(3 \%)$ for age category more than 60 years.

2) The highest percentage for "education" reached (40.7\%) for master holders, but the lowest percentage reached $(14 \%)$ for other holders.

3) The highest percentage for clinical degree background reached (46.1\%) for specialists, but the lowest percentage reached (20\%) for residents.

4) The highest percentage for "experience" reached (27.6\%) for 16-20 years, but the lowest percentage reached $(16.9 \%)$ for more than 20 years.

8.2 Research Variables Tests (Mean, SD)

Mean and standard deviation for items factor "governmental regulations":

Table 3. Mean, standard deviation, and Chi-square

\begin{tabular}{llcccc}
\hline No. & Items & Mean & S.D & Chi-square & P-Value \\
\hline 1 & The policy of privatization & 3.509 & 1.35 & 22.50 & 0.03 \\
2 & The policy for health insurance for Saudi people & 3.422 & 1.32 & 33.42 & 0.04 \\
3 & Governmental control by the Ministry of Defense & 4.477 & 1.30 & 31.47 & 0.04 \\
4 & Armed Forces Medical Service funds & 3.501 & 1.25 & 33.57 & 0.02 \\
5 & Medical training approval by Saudi Council for Health Specialties & 4.201 & 1.32 & 33.29 & 0.03 \\
\hline & Governmental Regulations & 3.822 & & & \\
\hline
\end{tabular}

Table 3 shows that the mean ranges from (3.422-4.477), with the highest mean being for item (3) "Governmental control by the Ministry of Defense", but the lowest mean was for item (2) "The policy for health insurance for Saudi people". The overall mean for "governmental factor" was (3.822).

Regarding the Chi square test the table shows that all five items are significant.

Mean and standard deviation for items factor "competitors": 
Table 4. Mean and standard deviation for items and Chi-square test

\begin{tabular}{|c|c|c|c|c|c|}
\hline No. & Items & Mean & S.D & Chi-square & P-Value \\
\hline 1 & Size of Saudi health market & 3.44 & 1.32 & 28.50 & 0.05 \\
\hline 2 & The competitors' old experience in the Saudi health market & 3.42 & 1.31 & 22.42 & 0.03 \\
\hline 3 & $\begin{array}{l}\text { Size and magnitude of local competition (number of local market } \\
\text { competitors) }\end{array}$ & 3.21 & 1.25 & 26.47 & 0.04 \\
\hline 4 & $\begin{array}{l}\text { External competition -external investment in the health sector (non-Saudi } \\
\text { hospitals) }\end{array}$ & 3.45 & 1.36 & 24.57 & 0.05 \\
\hline 5 & External competition -treatment outside Saudi, USA & 3.11 & 1.26 & 26.29 & 0.05 \\
\hline \multirow[t]{2}{*}{6} & $\begin{array}{l}\text { Unexpected additional marketing efforts done by local competitors by } \\
\text { using updating technology }\end{array}$ & 3.15 & 1.31 & 28.29 & 0.04 \\
\hline & Competitors & 3.29 & & & \\
\hline
\end{tabular}

Table 4 shows that the mean ranges from (3.11-3.45), with the highest mean for item (4) "External competitionexternal investment in the health sector (non-Saudi hospitals)", but the lowest mean for item (5) "External competition -treatment outside Saudi, USA". The overall mean for "competitors" was (3.29).

Regarding the Chi-square test, the table shows that all six items are significant.

\section{Mean and standard deviation for items factor "suppliers:"}

Table 5. Mean and standard deviation for items and Chi-square test

\begin{tabular}{|c|c|c|c|c|c|}
\hline No. & Items & Mean & S.D & Chi-square & P-Value \\
\hline 1 & $\begin{array}{l}\text { The quality of advanced medical equipment not yet available in } \\
\text { Saudi's health market }\end{array}$ & 4.78 & 1.21 & 38.51 & 0.00 \\
\hline 2 & $\begin{array}{l}\text { The quality of advanced medical equipment availability in Saudi's } \\
\text { health market }\end{array}$ & 4.68 & 1.40 & 28.42 & 0.01 \\
\hline 3 & Updated methods of diagnosing and treating diseases & 4.80 & 1.28 & 29.47 & 0.00 \\
\hline 4 & Availability of maintenance of medical equipment & 4.14 & 1.33 & 34.57 & 0.02 \\
\hline 5 & Effect of telemedicine services with other Saudi hospitals & 4.05 & 1.24 & 36.29 & 0.05 \\
\hline 6 & Size of hospital's suppliers & 4.78 & 1.21 & 38.50 & 0.01 \\
\hline 7 & Our suppliers are very important to our brand & 4.68 & 1.40 & 42.43 & 0.03 \\
\hline 8 & $\begin{array}{l}\text { Our suppliers are technological market leaders in our components } \\
\text { /material which we need }\end{array}$ & 4.90 & 1.28 & 36.42 & 0.00 \\
\hline 9 & Our suppliers have a wide range of different items & 4.14 & 1.33 & 34.51 & 0.01 \\
\hline 10 & $\begin{array}{l}\text { We can easily replace our suppliers with other comparative } \\
\text { suppliers }\end{array}$ & 4.06 & 1.24 & 36.22 & 0.03 \\
\hline & Suppliers & 4.51 & & & \\
\hline
\end{tabular}

Table 5 shows that the mean ranges from (4.05-4.90), with the highest mean for item (8) "Our suppliers are technological market leaders in our components /material which we need", and the lowest mean for item (5) "Effect of telemedicine services with other Saudi hospitals". The overall mean for "suppliers" was (4.51).

Regarding the Chi-square test, the table shows that all suppliers items are significant.

\section{Mean and standard deviation for items factor "patients":}

Table 6. Mean and standard deviation for items and Chi-square test

\begin{tabular}{llcccc}
\hline No. & Items & Mean & S.D & Chi-square & p-value \\
\hline 1 & Hospital's internal patients & 3.77 & 1.11 & 23.41 & 0.02 \\
2 & Hospital's referral patients & 2.61 & 1.40 & 21.37 & 0.03 \\
3 & Patients' needs and wants & 4.35 & 1.28 & 24.27 & 0.02 \\
4 & Increasing health awareness for Saudi people & 2.19 & 1.23 & 36.21 & 0.03 \\
5 & The Saudi patients' confidence rate in our health services & 4.09 & 1.24 & 28.20 & 0.04 \\
6 & The non-Saudi patients' confidence rate in our health services & 2.77 & 1.21 & 22.13 & 0.05 \\
7 & Patients' attitude toward foreign hospitals (e.g. American hospitals) & 2.40 & 1.30 & 18.50 & 0.04 \\
8 & Patients' protection legislation & 3.35 & 1.18 & 22.43 & 0.03 \\
\hline & Patients & 3.19 & & & \\
\hline
\end{tabular}


Table 6 shows that mean ranges from (4.35-2.19), with the highest mean for item (3) "Our patients' needs and wants", and the lowest mean for item (4) "Increasing health awareness for Saudi people". The overall mean for "patients" was (3.19).

Regarding the Chi-square test, the table shows that all patients' items are significant.

\section{Mean and standard deviation for items factor "public":}

Table 7. Mean and standard deviation for items and Chi-square test

\begin{tabular}{llcccc}
\hline No. & Items & Mean & S.D & Chi-square & P-Value \\
\hline 1 & Local public (e.g. media public) & 2.71 & 1.21 & 23.31 & 0.05 \\
2 & Increased numbers of retired staff & 2.61 & 1.40 & 22.31 & 0.05 \\
3 & International health campaign (e.g. breast cancer day) & 2.91 & 1.28 & 24.97 & 0.02 \\
4 & Volunteers (e.g. blood donation; donate for renal transplant) & 2.12 & 1.33 & 26.21 & 0.03 \\
\hline & Public & 2.58 & & & \\
\hline
\end{tabular}

Table 7 shows that the mean ranges from (2.12-2.91), with the highest mean for item (3) "International health campaign (e.g., breast cancer day)", and the lowest mean for item (4) "Volunteers (e.g. blood donation; donate for renal transplant)". The overall mean for "public" was (2.58).

Regarding the Chi-square test, the table shows that all public items are significant.

\section{Mean and standard deviation for item factor "health service providers":}

Table 8. Mean and standard deviation for items and Chi-square test

\begin{tabular}{llcccc}
\hline No. & Items & Mean & S.D & Chi-square & p-value \\
\hline 1 & Attitudes of health services providers & 4.57 & 1.21 & 31.37 & 0.01 \\
2 & Professional degree & 4.61 & 1.40 & 34.87 & 0.00 \\
3 & Incentives of health service providers & 4.35 & 1.24 & 33.91 & 0.02 \\
4 & Training and academic courses & 4.14 & 1.36 & 38.20 & 0.00 \\
5 & External experts (e.g. Western) & 4.44 & 1.24 & 32.23 & 0.00 \\
\hline Health service providers & 4.42 & & & \\
\hline
\end{tabular}

Table 8 shows that the mean ranges from (4.14-4.61), with the highest mean for item (2) "Professional degree", and the lowest mean for item (4) "Training and academic courses". The overall mean for "health service providers" was (4.42).

Regarding the Chi-square test, the table shows that all health service providers' items are significant.

Mean and standard deviation for item factor "health service development":

Table 9. Mean and standard deviation for items

\begin{tabular}{llcc}
\hline No. & Items & Mean & S.D \\
\hline 1 & Has a distinguished hospital brand name & 4.73 & 1.21 \\
2 & Understands patients' needs in order to develop new health services & 4.92 & 1.49 \\
3 & Offers a considerable (comprehensive) range of healthcare types (classes) & 4.35 & 1.34 \\
4 & Uses patients' service as a central element in our service offering strategy & 4.14 & 1.26 \\
5 & Uses patients' feedback to improve the quality and efficiency of our health service & 4.06 & 1.24 \\
6 & Has a good capacity to hold huge numbers during disastrous time & 3.60 & 1.12 \\
\hline Health service development & 4.30 & \\
\hline
\end{tabular}

Table 9 shows that the mean ranges from (3.60-4.92), with the highest mean for item (2) “Understands patients' needs in order to develop new health services", and the lowest mean for item (6) "Has a good capacity to hold huge numbers during disastrous time". The overall mean for "health service development" was (4.30). 


\subsection{Research Dimensions}

Table 10. Chi-square test

\begin{tabular}{lllllll}
\hline Independent Variables & Government & Competitors & Suppliers & Patients & Public & Health Services provider \\
\hline Chi-square & 84.243 & 128.126 & 98.283 & 72.213 & 138.146 & 98.823 \\
Df & 20 & 20 & 20 & 20 & 20 & 19 \\
Asymp. Sig. & .000 & .001 & .000 & .004 & .002 & .000 \\
\hline
\end{tabular}

Dependent variable: Health service development

a. 0 cells $(0.0 \%)$ have expected frequencies less than 5 . The minimum expected cell frequency is 14.7 .

b. 0 cells $(0.0 \%)$ have expected frequencies less than 5 . The minimum expected cell frequency is 15.4 .

\section{The general hypothesis in this research is:}

There is a significant relationship between stakeholders and health services.

The research sub-hypotheses are as follows:

1) There is a significant relationship between governmental factors and health services development.

2) There is a significant relationship between competitors and health services development.

3) There is a significant relationship between suppliers and health services development.

4) There is a significant relationship between patients and health services development.

5) There is a significant relationship between public and health services development.

6) There is a significant relationship between health service providers and health services development.

All of the six research hypotheses were accepted and the null hypotheses rejected.

\section{Research Discussion}

There was one single group participating in this research: that of the surgery department at KFGH in Jeddah. Empirically, the model assumed that stakeholders' factors influence health service development. It additionally predicted that the influence of such factors on health service development would differ according to the personal variables i.e., position and experience.

This empirical evidence has provided significant support for the stakeholder literature, which advocates that stakeholder factors have an influence on the organization and health service development (Robson et al., 2002; Chaharbaghi \& Nugent, 2004; Hough \& White, 2004).

The empirical evidence presented the view that the stakeholder factors have a fundamental role to play in the health service development in Saudi hospitals.

The result has indicated that the government is an influential factor on the health service development at KFGH. The conduct of government regulations represents a major influence on the health service development for this hospital, due to diverse policies and strategies formulated by governmental ministries and departments.

Competitors are considered as one of the influential factors on the KFGH. In Saudi's health market, there are various kinds of competitors: $\mathrm{MOH}$ hospitals, National Guard hospitals, university hospitals, and private hospitals. Lastly is competition within the same sector in different regions.

These findings are not surprising due to the fact that when KFGH challenges all these competitors, this might affect positively the development of health services for all. These findings are consistent with other researchers' findings. Higgins (1991) found that competition in healthcare enhances quality.

The result has indicated that the suppliers are an influential factor on health service development at KFGH. This finding is consistent with other researchers' findings. Kotler (1984) identified suppliers as a major factor influencing health service development, and also advocated hospital-supplier partnerships as a means to improve productivity, to control costs, and to improve quality of care. He suggests that long-term relationships with suppliers based on trust, service, and effective coordination could lead to efficiencies and improved performance.

Breen \& Crawford (2005) remarked that though hospitals of different sizes confront the challenge of finding novel means to increase productivity and quality of healthcare, some seek a new relationship with their suppliers to help lower costs and improve quality.

Patients are considered as one of the influential factors on health service development. 
A prerequisite for survival and growth is that both the hospital and its patients and other customers have an interest in their joint relationship. In other words, there should be a win-win situation. Improve the health service quality, reduce the waiting times etc.- these factors build an effective relationship and increase the hospital customer base in the long run. Patient satisfaction is considered to be of limited value, unless the hospital has environmental control as well.

The result has indicated that the health service provider is an influential factor on the health service development KFGH. The conduct of the health service provider represents a major influence on health service development for this hospital. Public also are considered as one of the influential factors on the KFGH.

\section{Conclusion and Recommendation}

The first is that most hospital managers do not consider the elements of stakeholders as crucial inputs. Stakeholders' information about government regulations, the policy of foreign investment, external competition, up-to-date medical technology, health insurance, customer preferences, and suppliers' influence are not utilized.

The main conclusion of this research is as follows:

Government regulations and legislations represent, to a great degree the most important factors influencing health service development. It is very necessary for both managers and researchers to investigate such factors and to seek answers to how, and to what extent government regulations influence health service development or how government regulations would improve the hospital performance by developing services. Competitors are a significant influential factor on health service development. KFGH managers can investigate the number of competitors in the health market and the kind of competition in the Saudi health market if there are any external competitors that influence the hospital. The supplier/ technology environment provides an opportunity for some KFGH to benefit through using up-to-date medical technology and their technically specialized labor-skills as a means of competing, and balancing the cost of using this technology against the profit gained. This can enhance the quality of health services and reduce the waiting time. On the other hand, it poses a threat in some cases, e.g. the budget is not available. Patient factor is one of the most influential in health service development. It is crucial for both hospital managers and researchers to investigate such factors and to ensure the extent to which hospitals comprehend the needs and wants of their patients when they provide them with health services. Public represents, to a great degree, the most important factors influencing the health service development. It is very necessary for managers to explore such factors and to seek answers to how, and to what extent, public influence health service development. Health service providers are considered as important factors influencing health service development. It is very necessary for managers to explore how health service providers influence positively the health service development, and what are the main factors influencing their performance towards high-quality health services.

Enhancing the awareness of stakeholder factors by studying the effects of government, competitors, suppliers, patients, public and health service providers. Hospital managers must investigate their patients' personal needs and wants in order to become aware of the local and international competitors, especially where unique specialists in different fields of medicine are to be found. Adopting and updating medical and non-medical technology to keep health service development. KFGH should build a strong relationship with the big companies and try to build partnerships with them, because they are considered as a big market for them. Hospital managers must investigate their health service providers' needs and wants in order to enhance their performance toward developing the hospital health service.

\section{References}

Ahmad, A. (2012). Macro-environment Influences on Health Service Strategy in Saudi Private Sector Hospitals: An Empirical Investigation. International Business Research, 5(5), 49. https://doi.org/10.5539/ibr.v5n5p49

Begun, J. W., \& Kaissi, A. A. (2004). Uncertainty in health care environments: myth or reality?. Health Care Management Review, 29(1), 31-39. https://doi.org/10.1097/00004010-200401000-00005

Breen, L., \& Crawford, H. (2005). Improving the pharmaceutical supply chain assessing the reality of e-quality through e-commerce application in hospital pharmacy. International Journal of Quality \& Reliability Management, 22(6), 572-590. https://doi.org/10.1108/02656710510604890

Chaharbaghi, K., \& Nugent, E. (1994). Towards the Dynamic Organization. Management Decision, 32(6), 45-48. https://doi.org/10.1108/00251749410065132

Cummings, S. R., Black, D. M., Nevitt, M. C., Browner, W. S., Cauley, J. A., Genant, H. K., ... \& Vogt, T. M. (1990). Appendicular bone density and age predict hip fracture in women. Jama, 263(5), 665-668. 
https://doi.org/10.1001/jama.1990.03440050059033

Emerson, C. J., \& Grimm, C. M. (1999). Buyer-seller customer satisfaction: the influence of the environment and customer service. Journal of Business \& Industrial Marketing, 14(5/6), 403-415. https://doi.org/10.1108/08858629910290201

Green, R., Rockmore, B., \& Zimmerer, T. (1995). The impact of environmental turbulence on American hospital strategies. Journal of Management in Medicine, 9(6), 6-15. https://doi.org/10.1108/02689239510101076

Higgins, C. (1991). Myths of competitive reform. Health Care Management Review, 16(1), 65-72. https://doi.org/10.1097/00004010-199101610-00009

Hitt, M., \& Hillman, A. (1999). Corporate Political Strategy Formulation: A Model of Approach, Participation, and Strategy Decisions. Academy of Management Review, 24(4), 825-842.

Hough, J., \& White, M. (2004). Scanning actions and environmental dynamism Gathering information for $\begin{array}{llll}\text { strategic decision making. } & \text { 781-793. }\end{array}$ https://doi.org/10.1108/00251740410542348

Kotler, N. G., Kotler, P., \& Kotler, W. I. (2008). Museum marketing and strategy: designing missions, building audiences, generating revenue and resources. Hoboken, New Jersey: John Wiley \& Sons.

Kotler, P. (1984). Social marketing of health behavior. Marketing health behaviour (pp. 23-39). New York: Springer US. https://doi.org/10.1007/978-1-4899-0366-2_2

Scrivens, E. (1991). Is there a role for marketing in the public sector?. Public Money \& Management, 11(2), 17-23. https://doi.org/10.1080/09540969109387650

Wheelen, T. L., \& Hunger, J. D. (2002). Strategic Management and Business Policy.

\section{Copyrights}

Copyright for this article is retained by the author, with first publication rights granted to the journal.

This is an open-access article distributed under the terms and conditions of the Creative Commons Attribution license (http://creativecommons.org/licenses/by/4.0/). 